\title{
Synchrony in lemming and vole populations in the Canadian Arctic
}

\author{
Charles J . Krebs, Alice J . Kenney, Scott Gilbert, Kjell Danell, Anders Angerbjörn, \\ Sam Erlinge, Robert G. Bromley, Chris Shank, and Suzanne Carriere
}

\begin{abstract}
Population fluctuations may occur in synchrony among several rodent species at a given site, and they may occur in synchrony over large geographical areas. We summarize information on synchrony in lemmings and voles from the Canadian Arctic for the past 20 years. The most detailed available information is from the central Canadian Arctic, where snap-trap samples have been taken annually at several sites for periods of up to 15 years. Geographical synchrony in the same species among different sites was strong, especially for the central and eastern Canadian Arctic. Synchrony among different species at a given site was also generally high. When one species is at high density, densities of all species at that site tend to be high. These results do not easily fit the mobile-predator hypothesis proposed to explain regional synchrony, and are more consistent with the weather hypothesis, which we suggest both entrains synchrony among sites and enforces synchrony among species within a site. We tentatively support the weather hypothesis for geographical synchrony in lemmings, and recommend the establishment of a circumpolar program to monitor lemming cycles and predator movements that would advance our understanding of these large-scale patterns of cyclic synchrony.
\end{abstract}

Résumé : Les densités de plusieurs espèces de rongeurs peuvent fluctuer en même temps à un endroit donné et ces fluctuations peuvent aussi être synchrones sur une échelle géographique très grande. Nous résumons ici des informations sur le synchronisme des lemmings et des campagnols dans l'arctique canadien depuis 20 ans. Les informations les plus detaillées proviennent de la région centrale de l'arctique, où des recensements annuels par trappage destructif ont été effectués à plusieurs sites pour une période allant jusqu'à 15 ans. Pour chaque espèce, le synchronisme géographique entre les différents sites est très fort entre les différents sites, et plus spécialement aux sites du centre et de l'est de l'arctique canadien. De même, le synchronisme entre les différentes espèces d'un même site est habituellement fort. Quand la densité d'une espèce devient haute, les densités de toutes les espèces à cet endroit ont aussi tendance à augmenter. Ces résultats sur le synchronisme géographique sont difficilement attribuables à l'hypothèse des prédateurs mobiles, mais semblent plutôt reliés à l'hypothèse météorologique selon laquelle les conditions météorologiques entraînent le synchronisme entre les sites et, de plus, forcent les espèces à être synchrones à un même site. Nous croyons pouvoir supporter l'hypothèse météorologique dans le cas du synchronisme géographique des lemmings et recommandons un suivi à l'échelle circumpolaire du cycle des lemmings et des déplacements des prédateurs ce qui contribuerait à parfaire nos connaissances sur les cycles synchrones à grande échelle.

\section{Introduction}

Lemming (Lemmus trimucronatus and Dicrostonyx spp.) populations form the basis of much of the terrestrial food chain of the Canadian Arctic, and often fluctuate dramatically in size (Elton 1942). There has been much discussion on these fluctuations and rather less research. The early surveys by the Canadian Arctic Wild Life Enquiry from 1933 to 1949 (Chitty 1950) suggested, based on questionnaire re- turns, that lemming cycles were often synchronous over very large geographic regions. But in many cases, sites relatively close to each other reported opposite phases, and Chitty (1950) concluded that more detailed research on the ground was needed to clarify the situation.

Two aspects of synchrony must be distinguished. Spatial synchrony refers to populations of the same species fluctuating in phase over large geographic regions. The scale of spatial synchrony must be more than $10-20 \mathrm{~km}$ of continuous

Received 26 November 2001. Accepted 5 July 2002. Published on the NRC Research Press Web site at http://cjz.nrc.ca on 29 August 2002.

C.J. Krebs ${ }^{1}$ and A.J. Kenney. Department of Zoology, University of British Columbia, Vancouver, BC V6T 1Z4, Canada. S. Gilbert. Renewable Resources Management Program, Yukon College, Whitehorse, YT Y1A 5K4, Canada.

K. Danell. Department of Animal Ecology, Swedish University of Agricultural Sciences, SE-901 83 Umea, Sweden.

A. Angerbjörn. Department of Zoology, Stockholm University, SE-106 91 Stockholm, Sweden.

S. Erlinge. Department of Animal Ecology, Lund University, SE-223 62 Lund, Sweden.

R.G. Bromley. Whole Arctic Consulting, Yellowknife, NT X1A 2N8, Canada.

C. Shank. Natural Resources Service, Box 1420, Cochrane, Alberta TOL 0W0, Canada.

S. Carriere. Department of Resources, Wildlife and Economic Development, Government of the Northwest Territories, 600,

5102 50th Avenue, Yellowknife, NT X1A 3S8, Canada.

${ }^{1}$ Corresponding author (e-mail: krebs@zoology.ubc.ca). 
habitat to ensure that populations are independent of local dispersal. Interspecific synchrony refers to all rodent species at a given site fluctuating in phase. It would be possible to have either one type of synchrony or both types together in a given area.

Hypotheses to explain spatial synchrony are based on three classes of mechanisms. (1) Predation: mobile predators may enforce spatial synchrony (Myrbeget 1973; Ydenberg 1987) and local predators could enforce interspecific synchrony (Henttonen and Hansson 1986; Swanson and Johnson 1999). (2) Weather: severe regional weather could force populations into phase by causing high mortality, or favorable regional weather could facilitate reproduction as well as survival (Leslie 1959). (3) Dispersal: local movements of lemmings and voles could synchronize populations within local areas. This mechanism could not operate for distances of hundreds of kilometres or for isolated islands. Only the first two hypotheses explain interspecific synchrony (Henttonen 1986). Note that in this paper we are attempting to investigate synchrony, and we do not consider the mechanisms that explain synchrony to be necessarily the same mechanisms that cause population cycles.

This paper draws together all the quantitative data we can locate on synchrony of lemming and vole populations in the Canadian Arctic since 1983 in order to answer three questions: (1) Does spatial synchrony of lemming and vole cycles occur in the Canadian Arctic? (2) Does interspecific synchrony occur? (3) Which of the three above-mentioned hypotheses, based on predation, weather, and dispersal, best fits our data. For the period 1983-2000 we will suggest that in the Canadian Arctic, spatial synchrony was very strong and that interspecific synchrony generally occurred.

\section{Methods}

We utilized four sources of data. First, we (C.J.K., A.J.K., S.G.) surveyed island and mainland sites in the western Canadian Arctic and central Arctic from 1987 to 2000. Our western Arctic surveys arose from our intensive research on the collared lemming (Dicrostonyx groenlandicus) at Pearce Point (Reid et al. 1995). In a typical year we surveyed five sites on both sides of the Mackenzie River from Horton River, Northwest Territories (N.W.T.), to Kay Point, Yukon Territory. Not all sites could be visited in all years. In the central Arctic we concentrated our surveys more locally and made use of the many islands in Bathurst Inlet to sample independent populations that were still in the same local region. We assume in this analysis that there are no large-scale movements of lemmings from mainland to island sites or between islands, so that all these sites have independent populations. We sampled 5 islands in Bathurst Inlet, the mainland at Hope Bay, Walker Bay on the Kent Peninsula, and Byron Bay on Victoria Island. These samples span a biogeographic boundary at which low-arctic rodents reach their range limits. The red-backed vole (Clethrionomys rutilus) and tundra vole (Microtus oeconomus) occur at Hope Bay but do not occur on the Kent Peninsula or on Victoria Island. Arctic ground squirrels (Spermophilus parryii) occur at Walker Bay and Hope Bay but do not occur on any of the small islands and have not yet been able to colonize Victoria Island.

Each site was trapped for 3 nights using 390 Museum
Special snap traps (a total of 1170 trap-nights). The traps were divided into lines of 20 stations, $15 \mathrm{~m}$ apart, with each station consisting of 3 traps within a $2-\mathrm{m}$ radius of the point, for a total of 60 traps per trap line. The minimum distance between parallel trap lines was $100 \mathrm{~m}$ and they were set out in a variety of vegetation habitats within a total area of approximately 100 ha. The traps were baited with peanut butter and on most traps we added raisins. We usually trapped in late June each year.

Our second source of data was the Small Mammal Survey coordinated by the Department of Renewable Resources, Government of the Northwest Territories, in Yellowknife. Chris Shank began this survey in 1991 and Suzanne Carriere has compiled it since 1998. Many observers contributed to the Small Mammal Survey, and although we tried to standardize methods of trapping to have them similar to those just described, not all the data were collected using uniform methods. An exception with organized and consistent methods was the time series from Walker Bay organized and collected by Bob Bromley and later by Deb Wilson (Wilson and Bromley 2001). Thirdly, the Swedish Tundra Northwest Expedition of 1999 visited 17 sites in the Canadian Arctic and surveyed lemming populations at each site (C.J.K., A.J.K., A.A., K.D., S.E.). We used the same type of snap trap lines in this expedition, but with a shorter period of 1-2 days, so we achieved 600-900 trap-nights per site. These data provide the largest scale overview of lemming numbers that we have for a single year over the whole Arctic. Finally, we have used some anecdotal data for a few sites in which cyclic phase was based, for example, on nesting snowy owls (Nyctea scandiaca).

Lemming and vole cycles in the mid-Arctic are typically of such high amplitude that one sample a year is sufficient to pinpoint a cyclic peak. In the High Arctic, fluctuations may not be so obvious without detailed quantitative data for a longer period of time.

In areas for which quantitative data are available, we have converted snap-trap catches to absolute density using the following regression: $\log ($ density (number per hectare $))=0.20277+$ 1.59146 (log number per 100 trap-nights) (C.J. Krebs, unpublished data). For surveys of lemming winter nests we have converted these to spring densities using the following regression: lemming density (number per hectare) $=0.3046 X^{2}+$ $0.0711 X$, where $X$ is the number of winter nests per hectare (C.J. Krebs, unpublished data). These conversions should be viewed as approximations rather than precise estimates.

There is considerable difficulty in defining "peak" populations in multispecies assemblages of rodents. For areas for which we have multiple years of data, we use a relativedensity criterion for a "peak", and we define a peak year as one in which the density of the particular species is higher in one year than in the preceding or following year. There are more precise biological indicators of cycles that could be used when more detailed demographic data are available (Krebs 1996), but many of the data reported here are not so detailed.

\section{Results}

Synchrony among sites

We divide our results geographically and present first the 
Fig. 1. Locations of study sites in the western $(a)$ and central (b) Canadian Arctic.

(a)

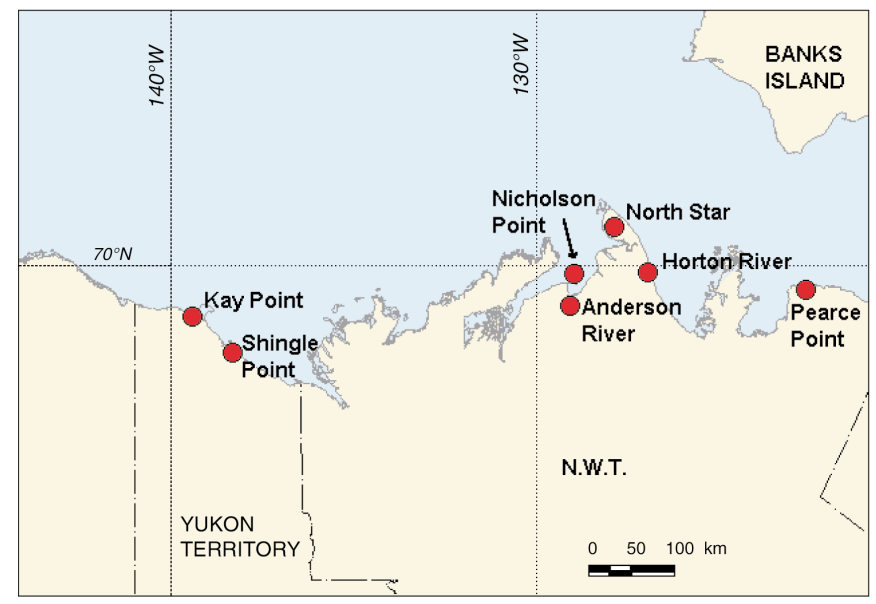

(b)

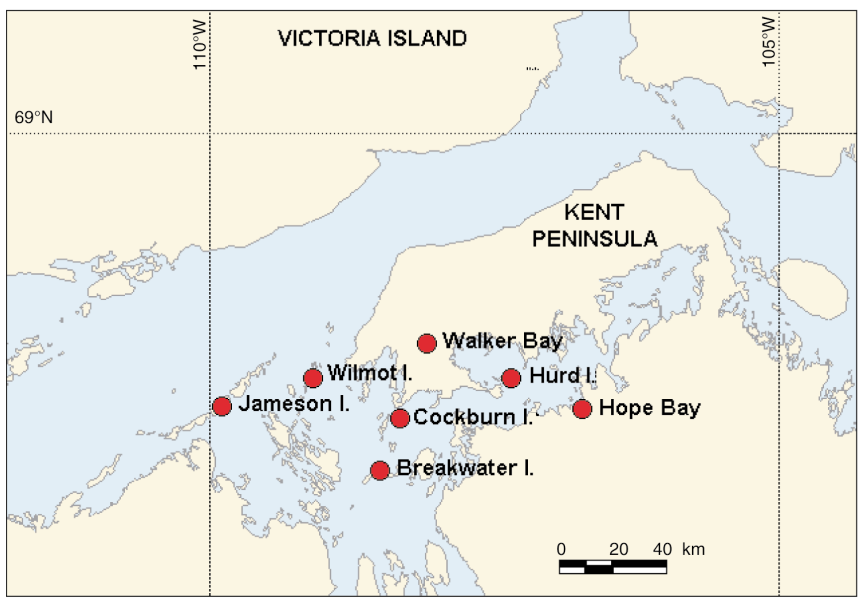

data from the western Arctic, then the central-Arctic surveys, and finally the Swedish Tundra Northwest Expedition data from 1999; the locations of all sites from the three datasets are shown in Figs. $1 a, 1 b$, and 5, respectively.

\section{Western Arctic}

Table 1 gives our qualitative results and Fig. 2 our quantitative results for two sites with the longest dataset. The sites east of the Mackenzie River from Horton River to Tuktoyaktuk seem to fluctuate and to do so in synchrony (Table 1). Microtus oeconomus and $C$. rutilus were often the dominant species at these sites. We were unable to detect any cyclic fluctuations at either of the two northern Yukon sites in the western Arctic, Kay Point and Shingle Point (Fig. 2b). Indices were never above 1.8 per 100 trap-nights for any species. If one interprets the relative peak at Kay Point in 1990 (index $=1.8$ for the tundra vole) and the relative peak at Shingle Point in 1994 (index = 0.6 for the brown lemming, Lemmus trimucronatus) as population highs, they are out of phase with each other and with those at sites east of the Mackenzie River (Table 1). The northern Yukon is a puzzle that we will return to later.
Fig. 2. Lemming and vole population indices for two western Arctic sites: Horton River, N.W.T. (a) and Shingle Point, Yukon (b). Small rodents were never abundant during any of the 8 years we sampled in northern Yukon (1989-1998).

(a)

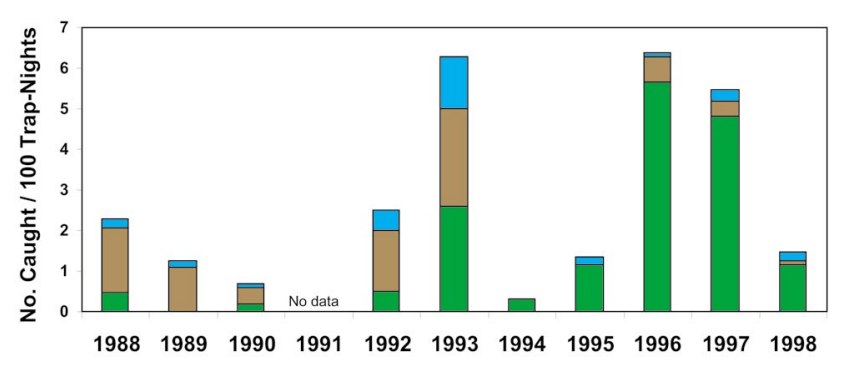

(b)

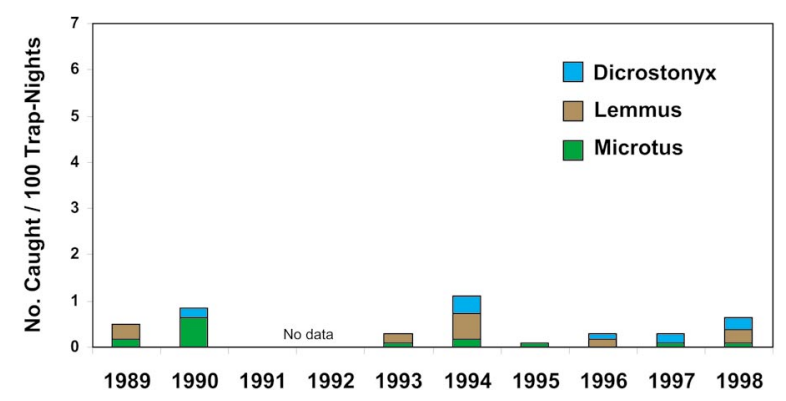

By contrast, Banks Island in the western Arctic has long been known for its strong lemming cycles (Maher 1967). Nic Larter (personal communication) has been trapping lemmings on southern Banks Island since 1993, and has reported peak populations of collared lemmings in 1993, 1996, and 2001. The 1993 and 1996 peaks were consistent with peaks at other sites east of the Mackenzie River (Table 1).

Snowy owl studies at Point Barrow, Alaska, since 1992 by Denver Holt have provided an index of brown lemming abundance at Barrow for the past decade. Snowy owls nested in abundance in 1993, 1995, and 1999 at Barrow (D. Holt, personal communication), suggesting a continuation of the strong brown lemming cycle in this part of the coastal plain. Table 1 shows that cycles at Barrow were in phase in 1993 but since then have not been in phase with other cycles in the western Arctic.

\section{Central Arctic}

Table 1 lists the peak years for all the sites we visited in the central Arctic from 1984 to 2000, and Fig. 3 illustrates the two longest time series from this region. Figure 4 gives the shorter time series of the Bathurst Inlet sites. Until 1999 the cyclic pattern and synchrony were very clear, with peaks in all areas in 1984, 1987, 1990, 1993, and 1996. A notable anomaly in the consistency of central-Arctic cycles of 3 years' duration occurred in 1999-2000, when populations at only two of the eight sites peaked in 1999 as expected, the others peaking in 2000. Wilmot Island and Jameson Island populations peaked in 1999. Lemmings on the other small islands and at Walker Bay, Hope Bay, and Byron Bay on Victoria Island reached a peak in 2000. 


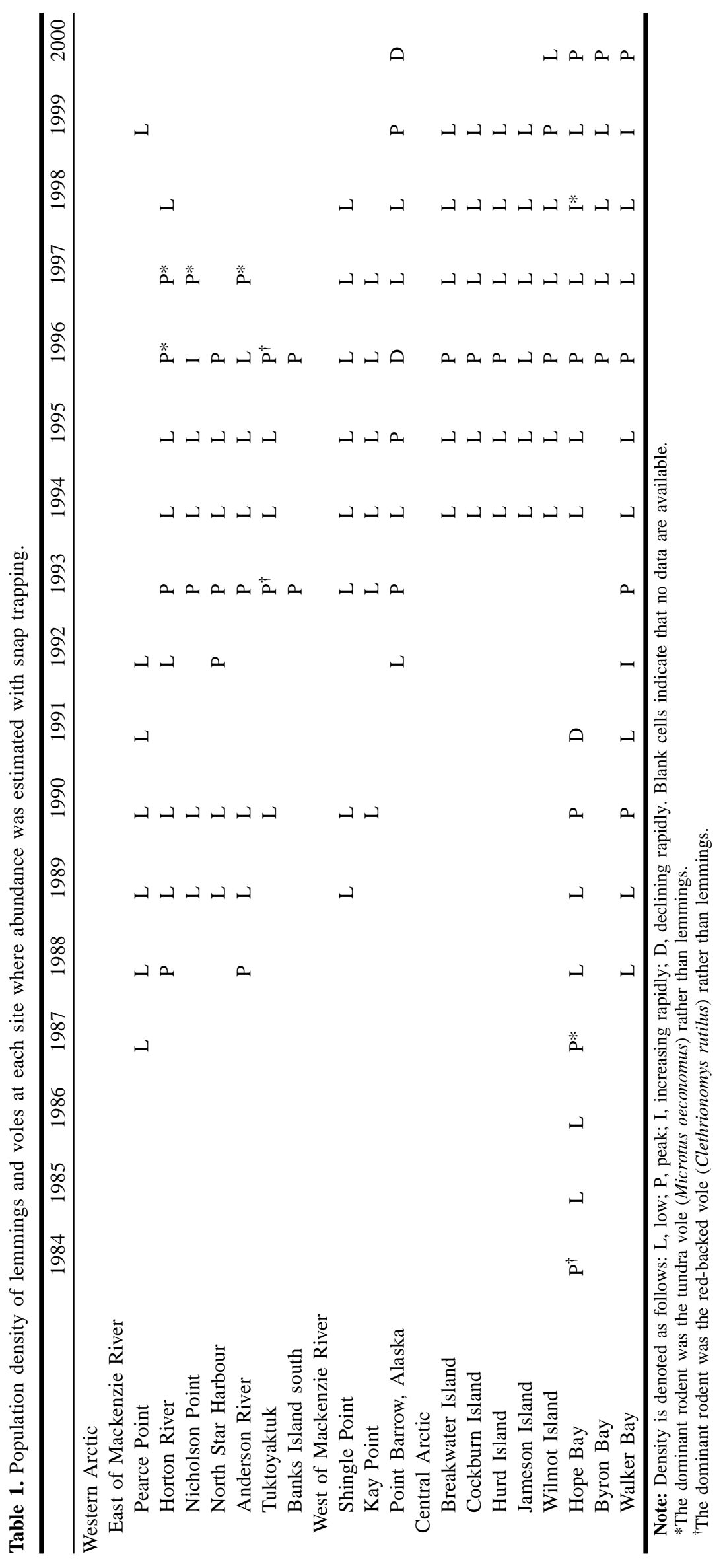


Fig. 3. Lemming and vole population indices for two central Arctic sites, Hope Bay, Nunavut (a) and Walker Bay, Nunavut (b). Populations of small rodents appeared to be in near-perfect synchrony in this region from 1984 to 2000.
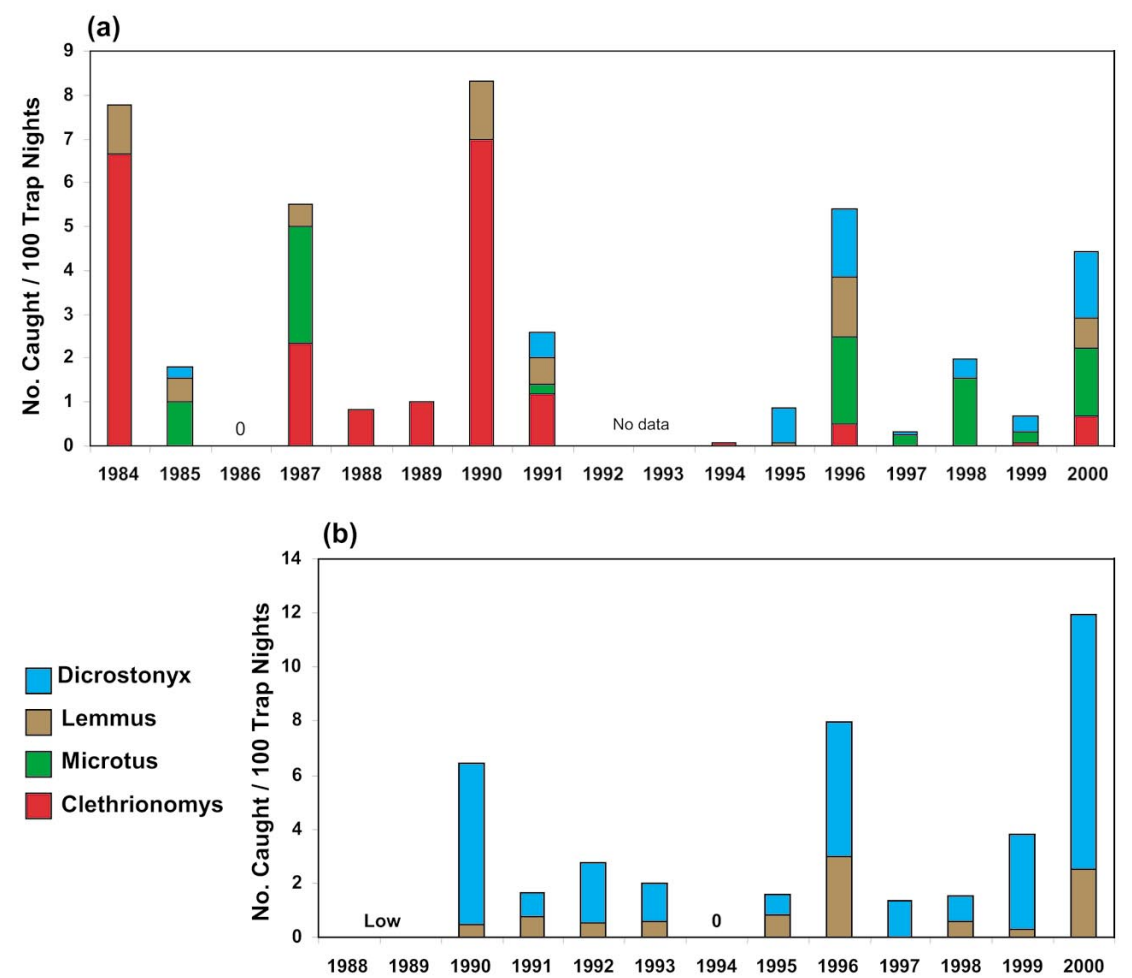

Synchrony in collared lemmings was very strong in this part of the central Arctic, with the exception of Wilmot Island. The index never reached 1.0 lemmings per 100 trapnights on Jameson Island in the 6 years it was surveyed, but the pattern of change was consistent with that on Wilmot Island. Walker Bay lemmings were already relatively abundant in 1999 but increased even more in 2000 (Fig. 3b). In contrast to other high-density years, there were virtually no predators to be seen at Walker Bay in 1999 (C.J. Krebs, personal observation), and this might have allowed high lemming populations to increase further in 2000 .

\section{Swedish Tundra Northwest Expedition in 1999}

The Swedish Tundra Northwest Expedition visited 17 sites scattered throughout the Canadian Arctic in the summer of 1999 (Fig. 5). Since we had experienced high lemming numbers at many sites in 1996, we anticipated a peak year for 1999. Instead we found low lemming numbers at all sites (Table 2). There is some difficulty in determining what a peak density of lemmings should be at High Arctic sites that have low primary productivity. We have assumed that a density of at least 10/ha should be a good indication of peak numbers (approximately 3 lemmings per 100 trap-nights), but this density cannot apply to areas of low primary productivity. For the Expedition data we have relied on a combination of density estimates from winter nests, which indicate approximate end-of-winter densities, and snap-trap catches, which indicate midsummer densities, to estimate the cyclic phase. If lemming numbers are changing rapidly, these two indices, given in Table 2, will differ. For example, Somerset Island showed high winter nest counts but low summer densities in
1999, which suggests the decline phase of a cycle. We do not know if lemmings at some of these sites are at low density all the time (cf. Reid et al. 1997). At two sites (Amundsen Gulf and Ivvavik), numbers of tundra voles were high in 1999.

There were two striking anomalies in the Swedish Tundra Northwest Expedition survey. Amundsen Gulf, which had a peak population of voles in 1999, is about $20 \mathrm{~km}$ east of Pearce Point. No cycles were evident at Pearce Point from 1987 to 1992 (Reid et al. 1995). We visited Pearce Point briefly via helicopter during the survey at Amundsen Gulf, and there was no sign of any rodent activity, in keeping with Reid et al.'s (1995) observations. Thus, two areas only $20 \mathrm{~km}$ apart were completely out of phase. Second, we found no high-density populations of rodents in 14 survey-years in the northern Yukon from 1989 to 1998 (Table 1), yet in 1999 tundra voles were at high numbers in Ivavvik National Park, a few kilometres to the west of Kay Point, in similar habitat. We have no simple explanation for these observations.

\section{Small Mammal Survey Information}

We can combine the survey's observations for 1999 with those of the Swedish Tundra Northwest Expedition to get a more global snapshot of synchrony. Bylot Island had a low density of lemmings in 1999 after earlier peaks in 1993 and 1996 (Bêty 2001). Kugluktuk had a high-density population of C. rutilus in 1999 (index =9.1). The lemming population at Daring Lake, south and east of Kugluktuk, was at low density in 1999 (index $=0.4$ ) after being at high density in 1996. These 1999 observations, along with the Swedish Tundra Northwest Expedition data from 1999 are illustrated in Fig. 6, which shows populations that are broadly categorized 
Fig. 4. Collared lemming (Dicrostonyx groenlandicus) population indices for six island and two mainland sites in the central Arctic. Except on Jameson Island and Wilmot Island in 1999, lemming populations appeared to be in synchrony in this region from 1994 to 2000.
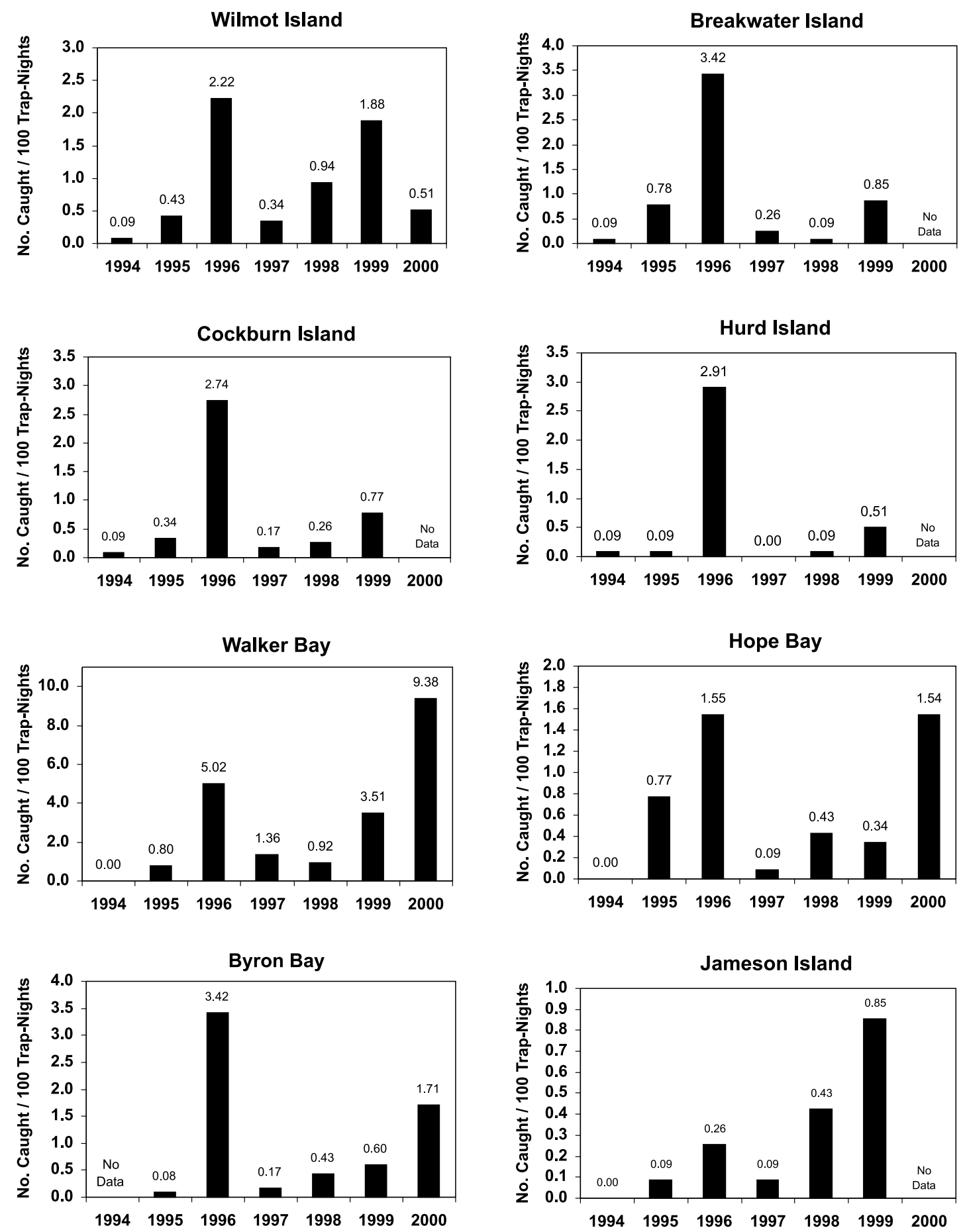

as high or low density. The snapshot of 1999 that emerges is one of widespread synchrony of low-density populations in the northern and eastern Arctic. Several sites in the western Arctic had high-density populations in 1999. Lemming populations in coastal northern Alaska were also at high density in 1999, as inferred from high numbers of nesting snowy owls (Table 1).

There is a suggestion from the Small Mammal Survey that

the barren grounds of the Low Arctic form a separate area of lemming synchrony that is sometimes out of phase with the mid-Arctic. Arviat on the west side of Hudson Bay had peak populations in 1990, 1993-1994, and 1997. Baker Lake and Rankin Inlet had peaks in 1994, and Coral Harbour on Southampton Island apparently had a lemming peak in 1997. The 1994 and 1997 peaks were certainly out of phase with the central mid-Arctic sites listed in Table 1. Unfortunately, 
Fig. 5. Map of the Canadian Arctic showing the locations of the 17 sites visited by the Swedish Tundra Northwest Expedition in summer 1999. For site names see Table 2. Squares denote towns and circles are sampling sites.

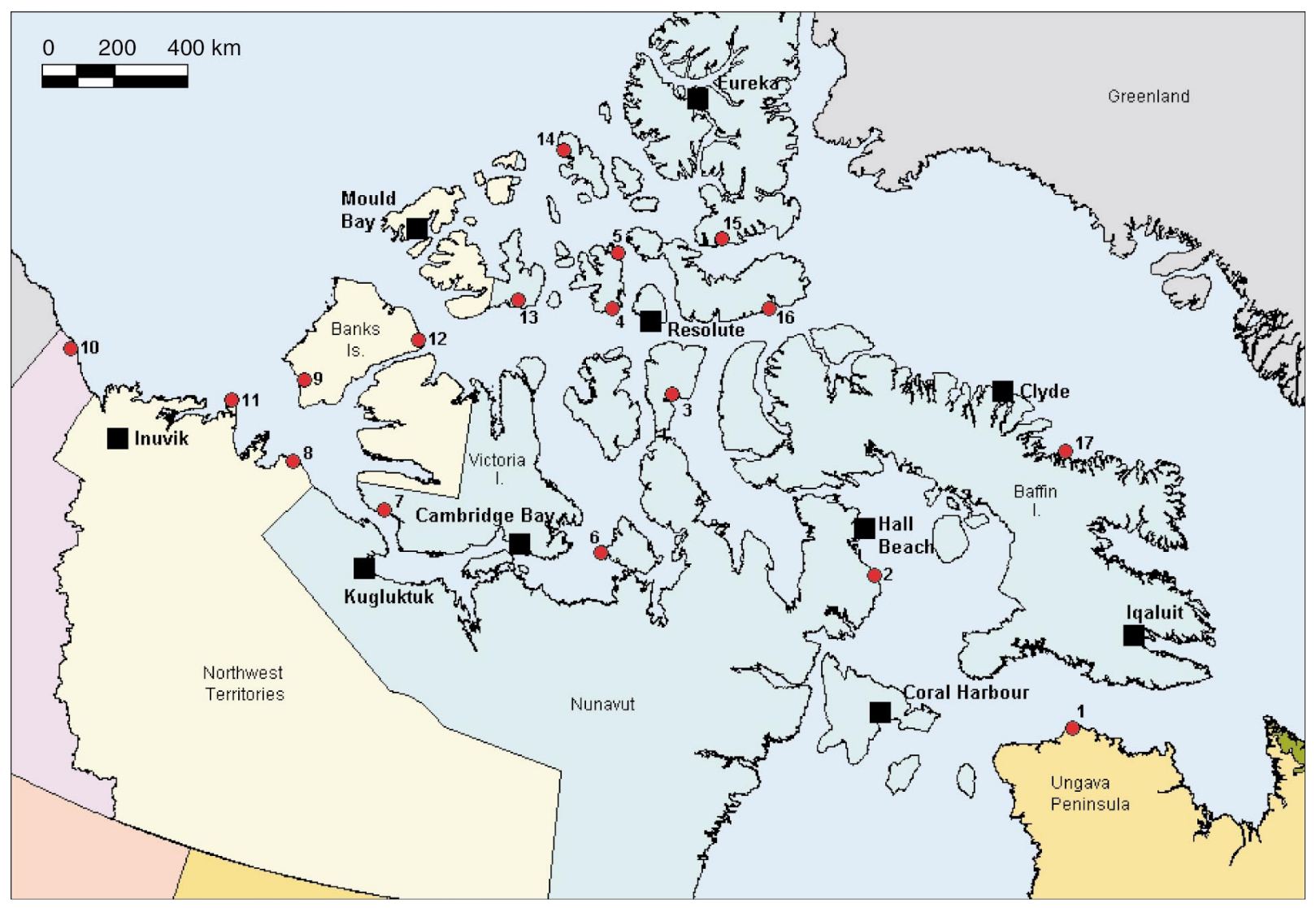

Fig. 6. Map of the Canadian Arctic showing the phase of the lemming and vole cycle at the 17 sites visited by the Swedish Tundra Northwest Expedition in summer 1999 and additional sites summarized in the Small Mammal Survey carried out by the N.W.T. Government. At the three western sites with high populations, these were largely Microtus oeconomus. One site in the central Arctic had a high population of collared lemmings. Lemming abundance was also high at Barrow, Alaska, in 1999.

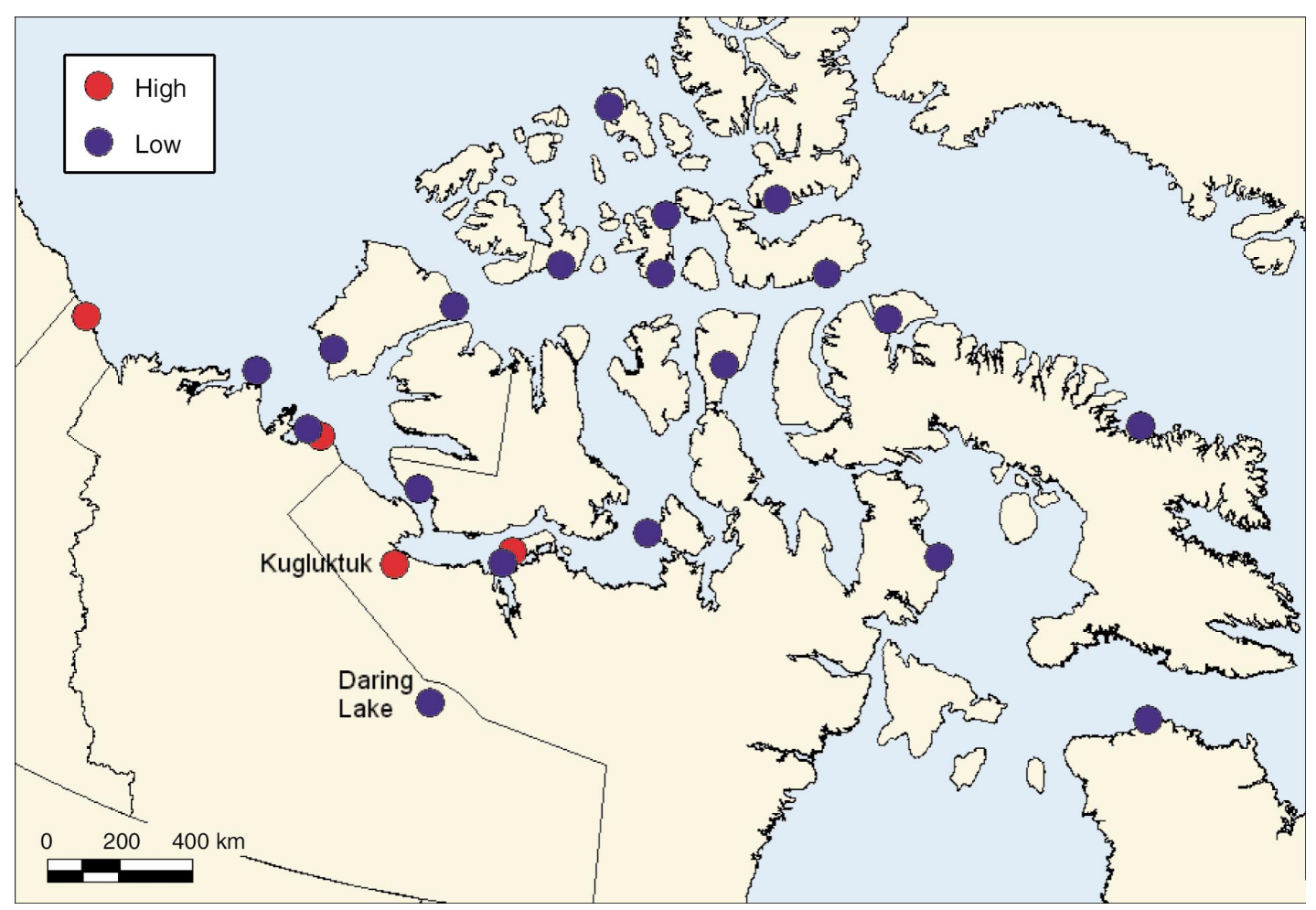


Table 2. Densities (number of individuals per hectare) of lemmings and voles at the 17 sites sampled by the Swedish Tundra Northwest Expedition in the summer of 1999.

\begin{tabular}{llcl}
\hline Site No. & Winter nests & Snap traps & Cyclic phase* \\
\hline 1. Ungava Peninsula & 0.01 & 0.1 & $\mathrm{~L}$ \\
2. Melville Peninsula & 0.8 & 0.4 & $\mathrm{~L}$ \\
3. Somerset Island & 2.8 & 0.01 & $\mathrm{~L}$ \\
4. Bathurst Island south & 0.8 & 2.0 & $\mathrm{I} ?$ \\
5. Bathurst Island north & 0.2 & - & $\mathrm{L}$ \\
6. King William Island & 0.7 & 0.07 & $\mathrm{~L}$ \\
7. Wollaston Peninsula & 0.3 & 0.01 & $\mathrm{~L}$ \\
8. Amundsen Gulf & $?^{\dagger}$ & 38.8 & $\mathrm{P}^{\ddagger}$ \\
9. Banks Island south & 1.1 & 2.4 & $\mathrm{~L}$ \\
10. Ivvavik National Park & $?^{\dagger}$ & 49.6 & $\mathrm{P}^{\dagger}$ \\
11. Cape Bathurst & 0.3 & 1.1 & $\mathrm{~L}$ \\
12. Banks Island north & 0.2 & 0.05 & $\mathrm{~L}$ \\
13. Melville Island & 0.3 & 0.3 & $\mathrm{~L}$ \\
14. Ellef Ringnes Island & 0.1 & 0.01 & $\mathrm{~L}$ \\
15. Ellesmere Island & 0.3 & 0.01 & $\mathrm{~L}$ \\
16. Devon Island & 3.8 & 1.3 & $\mathrm{~L}$ \\
17. Baffin Island (17) & 1.6 & 0.3 & $\mathrm{~L}$ \\
\hline
\end{tabular}

Note: Densities were estimated using the equations given in Methods.

*L, declining or low; P, peak; I, increasing.

${ }^{\dagger}$ Habitat was unsuitable for searching for winter nests.

*The dominant species was M. oeconomus.

the record of trapping at these Low Arctic sites over all the years listed in Table 1 was not continuous, so we have only spotty records from this region of the Low Arctic.

\section{Synchrony among species}

A second aspect of synchrony is whether or not different rodent species at a particular site fluctuate together in time. Our data on interspecific synchrony in the western and central Arctic are summarized in Figs. 2 and 3. It is clear that synchrony between species is common but not absolute. If we score all the species pairs shown in Figs. 2 and 3 for agreement in peak years, we find that in 28 of 46 instances (61\%) peaks coincide, so there is synchrony between species. Additional data from the Small Mammal Survey from seven sites in the eastern Arctic showed that peaks of different species coincided in 13 of 16 instances $(81 \%)$. If species operated at random, with 3 -year cycles we would expect $33 \%$ agreement and with 4 -year cycles only $25 \%$ agreement. In almost every case of asynchrony of peaks among species, the peak years are offset 1 year, and it is possible that some of these mismatches are the result of sampling variation. Clearly there is much more synchrony between separate species than would be expected by chance, if all these species have 3- to 4-year cycles.

The species composition during cyclic peaks can change dramatically from one cycle to the next. Figure 2 illustrates this for the Horton River site, where the same trap lines were used in most years. The 1993 peak included large numbers of both lemming species, as well as tundra voles, but the 1996 peak was almost entirely dominated by tundra voles. Brown lemmings were at a "peak" at the Horton River site in 1996, but their peak occurred at a low density. Collared lemmings were at a "peak" in 1997 at the Horton River site, when tundra voles were still quite abundant. Figure 3 shows this same type of shift at Hope Bay, which contains four species of rodents. The 1984 and 1990 peaks at Hope Bay were almost entirely dominated by red-backed voles, while this species played a minor role in the 1996 and 2000 peak years at the same site. The latter cycles were nearly equally dominated by brown lemmings, collared lemmings, and tundra voles. At sites that contain only the two lemming species (Fig. $3 b$ ) the composition of peak populations seems more consistent, and the two lemming species seemed to peak in the same years. This pattern may be linked with the habitat specialization of the two lemming species (Morris et al. 2000).

During the Swedish Tundra Northwest Expedition of 1999, lemmings (predominantly collared lemmings) were low in numbers throughout the Canadian Arctic, but at two sites (Amundsen Gulf and Ivavvik National Park), tundra voles were at peak densities.

\section{Discussion}

There has been increasing interest in the spatial dynamics of fluctuating populations (Bjørnstad et al. 1999; Ranta et al. 1997; Steen et al. 1996; Lambin et al. 1998). Our data are not as detailed at the local level as, for example, those of Saitoh et al. (1998) for Clethrionomys rufocanus on Hokkaido or Steen et al. (1996) for Norway. But we have two types of data that are uncommon, first a very large geographical scale of observations in some years, and second, detailed data on island populations in a regional setting.

In our analysis of synchrony we assume that lemming and vole populations in the Canadian Arctic normally have 3- to 4-year cycles. If we accept this assumption and also assume that populations are independent, we would expect that, in the absence of additional biological mechanisms, cycles would occur in a random pattern in time and space. This is the null model for studying synchrony. 
This null model does not fit our observations, and we can now answer the three questions posed in the Introduction. First, consider spatial synchrony. Lemming and vole populations in the central and eastern Canadian Arctic are highly synchronized when we group all species, with few populations out of phase. West of the Mackenzie River the picture is less clear and synchrony may be uncommon in this region. There was no synchrony between Shingle Point (Fig. 2) and Point Barrow, Alaska, in 1993 or 1995, but the peak populations in northern Yukon in 1999 were in phase with those in northern Alaska (and out of phase with those in eastern Canada). Smits and Slough (1992) surveyed fox dens on the Yukon Coastal Plain along the Arctic coast from 1984 to 1990 and found that only 1 or 2 of 50 dens were occupied in any of these years. They considered that arctic fox (Alopex lagopus) and red fox (Vulpes fulva) populations on the northern Yukon coast were at low density and showed no cyclic dynamics. The absence of population cycles in most years on the northern Yukon coast remains a puzzle.

Second, consider whether interspecific synchrony occurs in the Canadian Arctic. Synchrony between species of lemmings and voles at a single site is common: in most cases all species reach peak populations in the same year at a given site. Interspecific synchrony appears to be the rule in the $\mathrm{Ca}$ nadian Arctic.

Three mechanisms of synchrony among sites need to be evaluated in light of these data. Movements of lemmings and voles do indeed occur on a local scale (Ehrich et al. 2000), but they are insufficient to explain large-scale synchrony, such as that between populations at Walker Bay on the Kent Peninsula, Byron Bay on Victoria Island, and Hope Bay on the mainland (Fig. 1). The fact that, insofar as data are available, almost all sites in the eastern and central Canadian Arctic fluctuate in phase is incompatible with the localmovement hypothesis.

Movements of predators are potentially large-scale and have been favored by many as a major cause of regional synchrony (Myrberget 1973; Ydenberg 1987; Steen et al. 1996; Bjørnstad et al. 1999; Ims and Andreassen 2000). The problem lies in applying this mechanism to the entire eastern $\mathrm{Ca}$ nadian Arctic. Two predictions can be made if this is the postulated mechanism. (1) Because the area of synchrony is large, large-scale movements would have to occur between the Palaearctic and Nearctic regions. This scale of movement is possible with birds of prey, and is conceivable with arctic foxes, but there are few data at present to support this assumption. Satellite telemetry could be used to test this mechanism. Garrott and Eberhardt (1987) illustrated movement of arctic foxes as far as $2300 \mathrm{~km}$ from northern Alaska to the west side of Hudson Bay, suggesting that predator movements occur on a scale consistent with this hypothesis. (2) It should be impossible for this mechanism to operate if populations in Siberia, Canada, and Alaska are all in phase. We have very limited data showing that northern Yukon and Alaska were in a peak phase in 1999 and out of phase with the eastern Arctic, but we have no data from Siberia for this period. Erlinge et al. (1999) and Danell et al. (1999) showed that rodent cycles were out of phase regionally across Siberia, which suggests that mobile predators move from peak population to peak population around the Arctic circle.

We do not think that the mobile-predator hypothesis is a good explanation for our data. In particular, we found very few predators at any of the central Arctic sites in 1997 and 1998, which ought to have released lemming populations to reach a peak in 1999. This peak was seen at only a few sites (Fig. 6), often only a few kilometres apart. We think that mobile predators could enforce synchrony of lemming cycles on a regional scale of perhaps $50-100 \mathrm{~km}$, but would not be able to cause synchrony over subcontinental spatial scales. We suggest this as a hypothesis that needs to be tested by means of a globally coordinated study of predator movements in the Nearctic and Palaearctic.

Weather is the remaining agent that might synchronize lemming cycles at local, regional, and subcontinental scales. Because weather events are such large-scale phenomena, this hypothesis is the most difficult to test conclusively. When we began our study of the islands in the central Arctic, we assumed that the islands were linked only by weather events, since predators like arctic foxes and weasels were often missing from islands, even in the peak phase. That most of these islands were in phase with one another (with 2 exceptions in 36 island-years of data) suggests that weather, not mobile predators, is the main agent of synchrony.

One way to test for large-scale weather effects in the Canadian Arctic is to determine whether other species show synchrony of good and bad years. Geese can be severely impacted by late spring weather (Ganter and Boyd 2000), and the question arises as to whether independent goose colonies spread over the Arctic are affected at the same time. Ganter and Boyd (2000) showed a correlation between the 1991 eruption of Mount Pinatubo and a widespread breeding failure of waterfowl and waders in the Canadian Arctic in 1992. They tabulated data from Canadian Arctic goose populations to show that there was widespread breeding failure in other years, such as 1986. The key point is that severe weather in the Arctic can have a widespread geographical impact on nesting birds, and it is therefore possible that similar kinds of severe weather might act to synchronize small-mammal populations in the Arctic.

If we accept that a hierarchy of factors can synchronize cycles, we can begin to suggest explanations of the anomalous observations noted previously. If weather sets the stage for global synchrony, regional weather anomalies or local predator concentrations might cause deviations. For example, the expected lemming peak of 1999 might have been compromised by widespread poor weather (freezing rain causing direct mortality, a lack of snow increasing thermoregulatory energy demands and reducing reproductive rates; cf. Reid and Krebs 1996) in the autumn of 1998, with a few local exceptions like Wilmot Island. This kind of explanation is completely ad hoc, but as a hypothesis it can be tested by coordinating detailed weather recording and lemming population surveys.

The scale of rodent synchrony may also tell us something about the scale of weather synchrony. For the somewhat smaller Nearctic region, the rodent fluctuations presented in this paper indicate two areas of weather synchrony, but for the larger Palaearctic region, the patterns of lemming synchrony and asynchrony (Erlinge et al. 1999) indicate a more complex pattern with less homogeneous weather systems. This hypothesis can be tested with weather data.

A key unanswered question about the effects of weather 
on synchrony is how often weather must act to maintain synchrony over large regions. Since there is no known 3- to 4-year weather cycle that impacts a large part of the Canadian Arctic, it is clear that weather effects must occur as a more or less random pulse impacting lemming populations, as discussed in theoretical terms by Moran (1953) and Leslie (1959).

A corollary of the weather hypothesis of synchrony is that climate change in the Arctic in the coming decades will possibly alter patterns of synchrony. The need for a widespread program to monitor lemming cycles in the Canadian Arctic is thus clear, and this could be part of a larger program for monitoring the impacts of climate change on biodiversity. More detailed studies of the relationship between demography of lemmings and climatic variability are needed (Yoccoz and Ims 1999).

Synchrony between species at the same site has typically been explained by predation (Ims and Steen 1990), but there is no reason why weather cannot act on a suite of species in the same area, causing interspecific synchrony through the Moran effect (Ranta et al. 1995, 1997). Watson et al. (2000) suggested that weather was the agent synchronizing rock ptarmigan (Lagopus mutus) and red grouse (Lagopus lagopus scoticus) populations in Scotland. The problem with a weatherbased explanation for interspecific synchrony is that there is no particular reason to assume that all species will respond in exactly the same way to given weather conditions.

The conclusion that large-scale weather patterns set the stage for synchrony of lemming and vole cycles in the Canadian Arctic is compatible with an increasing set of papers in which weather is implicated in vertebrate population dynamics (Stenseth et al. 1999; Sæther et al. 2000; Saucy 1994; Moss et al. 2001). In ecology, weather has typically been thought of as a disturbance, a density-independent factor that can rarely be used to explain patterns in dynamics. Since Moran's early papers (e.g., Moran 1953), this viewpoint has been called into question, and we consider that weather is implicated as the major variable causing synchrony in Arctic lemming and vole populations.

We speculate that there could be a vegetation $\times$ weather interaction in Siberia and Canada that has an impact on spatial synchrony. The sparse and low heath vegetation that predominates in Canada may provide less favorable subnivean space for lemmings, in contrast to the grasslands that predominate in Siberia (Erlinge et al. 1999), so weather impacts are more severe in Canada. This type of vegetation $\times$ weather interaction might explain why tundra voles living in grasslandtype habitats in Canada were at high density in 1999, while collared lemmings and voles living in sparsely vegetated habitats were not.

We can see no evidence of traveling waves in lemming cycles in the Canadian Arctic similar to those reported for voles in Europe (Fichet-Calvet et al. 2000; Lambin et al. 1998; Sherratt et al. 2000) and red grouse in Scotland (Moss et al. 2000). This could be due to the coarse scale of resolution of the data available to us. A detailed analysis of a continuous regional patch of arctic habitat could resolve this issue.

To supplement the trapping data reported above (Table 1 and Fig. 4), Predavec et al. (2001) tested a dendrochronological method based on ageing of scarred willows (Danell et al. 1981), which has been useful in describing past microtine rodent fluctuations in the boreal forest. During 1994 and
1995, 18 sites were sampled, mainly in the central Arctic (cf. Fig. 1b). The data obtained for the period 1960-1994 showed no regular periodicity in the patterns of population change, and only sites that were geographically connected and close $(<6 \mathrm{~km})$ showed significant synchrony in fluctuations. There are at least three possible explanations for the failure of Predavec et al. (2001) to demonstrate synchrony in rodent fluctuations in the central Arctic for the period 1960 1994. The first is that bark feeding is not directly related to lemming population density on the tundra; the second is that tundra willows are more difficult to age than boreal willows (e.g., false annual rings appear, or there are no rings at all); the third is that the rodents showed no clear synchrony during 1960-1994, in contrast to the last 20 years (except 19992000). K. Danell (in preparation) is working on additional samples of willows from the Canadian Arctic and will report on these more extensive datasets in the future. However, our main conclusions in this paper concern the last 20 years and are based on trapping data alone.

We think that further progress in analyzing synchrony in lemming populations will come from global cooperation to monitor lemmings across Siberia, Canada, and Alaska in conjunction with a study of predator movements on a subcontinental scale. In particular, the arctic fox, snowy owl, rough-legged hawk (Buteo lagopus), and long-tailed jaeger (Stercorarius longicaudus) await studies using satellite telemetry. We think that island populations have not been utilized sufficiently as a quasi-experimental way of testing the mechanisms that have been suggested to generate synchrony in lemming and vole populations. Detailed studies of lemmings and their predators in island and mainland locations could help resolve which predators are necessary for cyclic dynamics and synchrony.

\section{Acknowledgements}

We thank the Polar Continental Shelf Project for helicopter and aircraft support that allowed us to complete these surveys. The Swedish Polar Secretariat provided complete funding for the Swedish Tundra Northwest Expedition of 1999 to the Canadian Arctic, and we appreciate their support. The Department of Renewable Resources of the N.W.T. supported the base camp at Walker Bay and maintained the survey records we used in our analysis. Liz Hofer and Peter Upton helped with the central Arctic surveys, and Peter Zurachenko and Rudy Boonstra assisted in the western Arctic surveys. The Natural Sciences and Engineering Research Council of Canada provided research funding to C.J.K. and A.J.K. We thank the many observers who contributed data to the Small Mammal Survey in the N.W.T. and Nunuvut. Patrick Carrier kindly provided the French translation of the Abstract.

\section{References}

Bêty, J. 2001. Interactions trophiques indirectes, predation, et strategies de reproduction chez l'oie des neiges nichant dans le hautartique. Ph.D. thesis, Departement de Biologie, Université Laval, Québec, Que. 
Bjørnstad, O.N., Stenseth, N.C., and Saitoh, T. 1999. Synchrony and scaling in dynamics of voles and mice in northern Japan. Ecology, 80: 622-637.

Chitty, H. 1950. Canadian Arctic Wild Life Enquiry, 1943-49: with a summary of results since 1933. J. Anim. Ecol. 19: 180193.

Danell, K., Ericson, L., and Jakobsson, K. 1981. A method for describing former fluctuations of voles. J. Wildl. Manag. 45: 1018-1021.

Danell, K., Erlinge, S., Högstedt, G., Hasselquist, D., Olofsson, E.B., Seldal, T., and Svensson, M. 1999. Tracking past and ongoing lemming cycles on the Eurasian tundra. Ambio, 28: 225229.

Ehrich, D., Fedorov, V.B., Stenseth, N.C., Krebs, C.J., and Kenney, A. 2000. Phylogeography and mitochondrial DNA (mtDNA) diversity in North American collared lemmings (Dicrostonyx groenlandicus). Mol. Ecol. 9: 329-337.

Elton, C. 1942. Voles, mice and lemmings: problems in population dynamics. Clarendon Press, Oxford.

Erlinge, S., Danell, K., Frodin, P., Hasselquist, D., Nilsson, P., Olofsson, E.-B., and Svensson, M. 1999. Asynchronous population dynamics of Siberian lemmings across the Palaearctic tundra. Oecologia (Berl.), 119: 493-500.

Fichet-Calvet, E., Pradier, B., Quere, J.P., Giraudoux, P., and Delattre, P. 2000. Landscape composition and vole outbreaks: evidence from an eight year study of Arvicola terrestris. Ecography, 23: 659-668.

Ganter, B., and Boyd, H. 2000. A tropical volcano, high predation pressure, and the breeding biology of arctic waterbirds: a circumpolar review of breeding failure in the summer of 1992. Arctic, 53: 289-305.

Garrott, R.A., and Eberhardt, L.E. 1987. Arctic fox. In Wild furbearer management and conservation in North America. Edited by M. Novak, J.A. Baker, M.E. Obbard, and B. Malloch. Ontario Ministry of Natural Resources, Toronto. pp. 395-406.

Henttonen, H. 1986. Causes and geographic patterns of microtine cycles. Ph.D. thesis, University of Helsinki, Helsinki, Finland.

Ims, R.A., and Andreassen, H.P. 2000. Spatial synchronization of vole population dynamics by predatory birds. Nature (Lond.), 408: 194-196.

Ims, R.A., and Steen, H. 1990. Geographical synchrony in microtine population cycles: a theoretical evaluation of the role of nomadic avian predators. Oikos, 57: 381-387.

Krebs, C.J. 1996. Population cycles revisited. J. Mammal. 77: 8-24.

Lambin, X., Elston, D.A., Petty, S.J., and MacKinnon, J.L. 1998. Spatial asynchrony and periodic travelling waves in cyclic populations of field voles. Proc. R. Soc. Lond. B Biol. Sci. 265: 1491-1496.

Leslie, P.H. 1959. The properties of a certain lag type of population growth and the influence of an external random factor on a number of such populations. Physiol. Zool. 32: 151-159.

Maher, W.J. 1967. Predation by weasels on a winter population of lemmings, Banks Island, Northwest Territories. Can. Field-Nat. 81: 248-250.

Moran, P.A.P. 1953. The statistical analysis of the Canadian lynx cycle. II. Synchronization and meteorology. Aust. J. Zool. 1: 291-298.

Morris, D.W., Davidson, D.L., and Krebs, C.J. 2000. Measuring the ghost of competition: insights from density-dependent habitat selection on the coexistence and dynamics of lemmings. Evol. Ecol. Res. 2: 41-67.

Moss, R., Elston, D.A., and Watson, A. 2000. Spatial asynchrony and demographic traveling waves during red grouse population cycles. Ecology, 81: 981-989.

Moss, R., Oswald, J., and Baines, D. 2001. Climate change and breeding success: decline of the capercaille in Scotland. J. Anim. Ecol. 70: 47-61.

Myrberget, S. 1973. Geographical synchronism of cycles of small rodents in Norway. Oikos, 24: 220-224.

Predavec, M., Krebs, C.J., Danell, K., and Hyndman, R. 2001. Cycles and synchrony in the collared lemming (Dicrostonyx groenlandicus) in arctic North America. Oecologia (Berl.), 126: 216-224.

Ranta, E., Lindstrom, J., and Linden, H. 1995. Synchrony in tetraonid population dynamics. J. Anim. Ecol. 64: 767-776.

Ranta, E., Kaitala, V., Lindstrom, J., and Helle, E. 1997. The Moran effect and synchrony in population dynamics. Oikos, 78: 136-142.

Reid, D.G., and Krebs, C.J. 1996. Limitations to collared lemming population growth in winter. Can. J. Zool. 74: 1284-1291.

Reid, D.G., Krebs, C.J., and Kenney, A.J. 1995. Limitation of collared lemming population growth at low densities by predation mortality. Oikos, 73: 387-398.

Reid, D.G., Krebs, C.J., and Kenney, A.J. 1997. Patterns of predation on noncyclic lemmings. Ecol. Monogr. 67: 89-108.

Saitoh, T., Stenseth, N.C., and Bjørnstad, O.N. 1998. The population dynamics of the vole Clethrionomys rufocanus in Hokkaido. Res. Popul. Ecol. 40: 61-76.

Saucy, F. 1994. Density-dependence in time-series of the fossorial form of the water vole Arvicola terrestris. Oikos, 71: 381-392.

Sherratt, T.N., Lambin, X., Petty, S.J., MacKinnon, J.L., Coles, C.F., and Thomas, C.J. 2000. Use of coupled oscillator models to understand synchrony and travelling waves in populations of the field vole Microtus agrestis in northern England. J. Appl. Ecol. 37: 148-158.

Smits, C.M.M., and Slough, B.G. 1992. Distribution and summer occupancy of fox dens in northern Yukon Territory 1984-1990. Tech. Rep. TR-92-1, Fish and Wildlife Branch, Yukon Renewable Resources, Whitehorse.

Steen, H., Ims, R.A., and Sonerud, G.A. 1996. Spatial and temporal patterns of small-rodent population dynamics at a regional scale. Ecology, 77: 2365-2372.

Stenseth, N.C., Chan, K.S., Tong, H., Boonstra, R., Boutin, S., Krebs, C.J., Post, E., O'Donoghue, M., Yoccoz, N.G., Forchhammer, M.C., and Hurrell, J.W. 1999. Common dynamic structure of Canada lynx populations within three climatic regions. Science (Washington, D.C.), 285: 1071-1073.

Swanson, B.J., and Johnson, D.R. 1999. Distinguishing causes of intraspecific synchrony in population dynamics. Oikos, 86: 265-274.

Sæther, B.-E., Tufto, J., Engen, S., Jerstad, K., Røstad, O.W., and Skåtan, J.E. 2000. Population dynamical consequences of climate change for a small temperate songbird. Science (Washington, D.C.), 287: 854-856.

Watson, A., Moss, R., and Rothery, P. 2000. Weather and synchrony in 10-year population cycles of rock ptarmigan and red grouse in Scotland. Ecology, 81: 2126-2136.

Wilson, D.J., and Bromley, R.G. 2001. Functional and numerical responses of predators to cyclic lemming abundance: effects on loss of goose nests. Can. J. Zool. 79: 525-532.

Ydenberg, R.C. 1987. Nomadic predators and geographical synchrony in microtine population cycles. Oikos, 50: 270-272.

Yoccoz, N.G., and Ims, R.A. 1999. Demography of small mammals in cold regions: the importance of environmental variability. Ecol. Bull. 47: 137-144. 